\title{
REPOSISI PENDIDIKAN SENI SEBAGAI SENTRA PEMBENTUKAN INSAN HUMANIS
}

\section{Sutiyono \\ FBS Universitas Negeri Yogyakarta (e-mail: sutiyono_63@yahoo.com)}

\begin{abstract}
Abstrak: Reposisi Pendidikan Seni sebagai Sentra Pembentukan Insan Humanis. Penelitian ini bertujuan untuk mendeskripsikan bentuk pembelajaran seni dan mengetahui indikasi proses pembentukan insan humanis. Penelitian ini dilakukan di Jurusan Pendidikan Seni Tari, Fakultas Bahasa dan Seni, Universitas Negeri Yogyakarta. Pengumpulan data dilakukan melalui observasi, wawancara mendalam, dokumentasi. Analisis data menggunakan teknik deskriptif kualitatif. Hasil penelitian ini menemukan bahwa: (1) bentuk pembelajaran seni pada mata kuliah praktik tari terintegrasi dengan nilai-nilai kemanusiaan terdiri dari: (a) nilai estetika, (b) nilai sosial, dan (c) nilai moral. Melalui proses pembelajaran seni ini para mahasiswa dibawa langsung pada pencapaian tiga ranah, yaitu kognitif, afektif, dan psikomotor; (2) indikasi proses pembentukan insan humanis terletak pada interaksi para mahasiswa di dalam/uar kelas dalam bentuk perilaku humanis, misalnya saling membantu dan bekerja sama dengan teman dalam mengikuti proses pembelajaran. Penemuan pertama disebut proses hominisasi (pembentukan kemanusiaan) dan penemuan kedua disebut proses humanisasi (pengamalan kemanusiaan).
\end{abstract}

Kata Kunci: pendidikan seni, humanisasi, nilai estetika, sosial, dan moral

\begin{abstract}
The Reposition of the Art Education as the Humanist Formation Centre. This study was aimed to describe the form of the art education and to reveal the indication of the humanist formation process. This study was conducted in the dance education department, the faculty of languages and arts, Yogyakarta State University. The data were collected through observations, in-depth interviews, and documentation. The data were analyzed using the descriptive qualitative technique. The findings showed that the teaching of art in the dance practice classes was integrated with humanistic values, including: (a) aesthetical values; (b) social values; and (c) moral values. Through the teaching of art, students are guided directly to the achievement of the three domains, that is, cognitive, affecttive, and psychomotor domains. The humanist formation was indicated through the interaction among students both inside and outside the class in the form of humanistic behavior, such as helping one another and working together with friends in the teaching process. The first finding was called the hominization process while the second finding was called the humanization process.
\end{abstract}

Keywords: art education, humanistic, aesthetic, social, and moral values 


\section{PENDAHULUAN}

Tidak dapat dipungkiri bahwa kemajemukan atas suku bangsa, agama, ras, dan golongan itu di satu sisi menggambarkan aset yang berharga. Di sisi lain, jika kemajemukan itu tidak dapat ditata dengan rapi, terjadinya perpecahan bangsa tidak dapat dihindari. Konflik kekerasan yang selama ini merambah terjadi di Sambas, Sampit (Kalimantan), Poso (Sulawesi), Ambon (Maluku), Aceh, dan Papua yang hingga sekarang kadang-kadang masih muncul ke permukaan merupakan gambaran sulitnya mengelola konflik. Termasuk berbagai bentuk kekerasan kecil yang terjadi di daerah-daerah, yang sering muncul ditayangkan media massa juga dapat dilihat sebagai indikasi sulitnya menata suatu kemajemukan.

Banyaknya kejadian konflik kekerasan di atas memperlihatkan bahwa pola pikir emosional masih mendominasi masyarakat Indonesia. Kenyataannya perilaku destruktif sering disebabkan oleh suatu kelompok kepentingan yang mengatasnamakan persaingan, permusuhan, perselisihan, pertengkaran, konflik, dan benturan sosial. Akibat yang ditangggung dari pola pikir emosional itu adalah sulitnya menuju pada kehidupan yang harmonis, serasi, selaras, dan seimbang. Atas nama pola pikir emosional itu, orang mudah menumpahkan emosinya dalam berbagai bentuk kekerasan. Perilaku kekerasan sering menjadi wahana yang menentukan dan satu-satunya cara untuk mengakhiri suatu persoalan. Namun demikian, Wils (2003:199) berharap agar suatu kekerasan dalam bentuk apa pun segera mendapat penanganan, tetapi hingga sekarang diagnosis untuk mengantisipasi terjadinya kekerasan masih tertunda pelaksanaannya.

Di Indonesia sendiri, obat penawar untuk menghadang datangnya suatu bentuk kekerasan belum pernah dibuat. Masyarakat sekadar berharap, sekiranya negara (pemerintah) dapat menjadi contoh-teladan berkarakter yang baik, tentu akan dapat ditiru oleh masyarakatnya. Kenyataannya, negara beserta kaki tangan (aparat) malah menjadi pihak yang melakukan kekerasan terhadap rakyatnya (Santosa, 2002). Demikian pula media massa sebagai penyebar informasi terbesar yang sekaligus diharapkan dapat memuat informasi tentang tayangan perilaku yang baik, kenyataannya malah bertindak sebagai penyebar informasi tentang kebrutalan dan kekerasan yang menjadi suguhan masyarakat seharihari. Pengaruh media massa sangat luar biasa terhadap pola tindakan masyarakat. Jika antara negara dan media telah menunjukkan kerusakan, jelas masyarakat ikut larut dalam kerusakan.

Tampaknya obat penawar satusatunya yang diharapkan dapat mengatasi persoalan kekerasan di Indonesia adalah pendidikan. Artinya, guna membentuk sesorang berkarakter baik, perlu ada rekayasa sosial yang diwujudkan melalui proses pendidikan. Tentu saja diharapkan dapat mewujudkan peserta didik yang berkarakter, yang dalam skup nasional akan melahirkan karakter bangsa. Dalam suatu karakter bangsa yang baik tercermin peran bangsa yang amat penting dan menen- 
tukan. Bangsa yang memiliki karakter keropos sulit untuk bisa maju. Dapat dinyatakan bahwa karakter merupakan segala-galanya bagi kemajuan suatu bangsa. Oleh karena itu, untuk menuju pada perwujudan karakter yang baik serta menjauhkan perilaku kekerasan setidak-tidaknya harus diproses melalui pendidikan.

Dalam hubungan ini, posisi pendidikan seni yang mengajarkan materi seni sering dianggap sebagai wadah pembelajaran yang strategis dalam membentuk manusia menuju karakter humanis dan mampu mejauhkan dari segala bentuk kekerasan. Selain itu, yang terpenting dari proses belajar mengajar dalam pendidikan seni, para mahasiswa merasa bertambah humanis, karena bagaimanapun mereka dituntut untuk saling kerjasama antarteman dalam mempelajari materi seni.

Belajar tentang seni tentu saja tidak hanya sekedar mempelajari praktik dan teknisnya, tetapi meliputi berbagai aspek misalnya nilai-nilai estetika dan etika yang menjadi poros budaya dari sebuah seni yang akan dipelajari. Poros budaya itu menunjang kelengkapan piranti nilai-nlai kehidupan manusia atau nilai-nilai humanisasi. Tampaknya, pembelajaran seni dapat memuat ilmu pengetahuan, keterampilan, nilainilai akhlak, dan sebagainya sehingga kesemuannya itu bermuara pada peningkatan kecerdasan majemuk (multiple intelligences).

Lembaga pendidikan memiliki tugas mempersiapkan terbentuknya individu-individu yang cerdas dan berakhlak mulia. Terbentuknya dua kriteria ini memungkinkan terwujudnya kehi- dupan sosial yang ideal, yang diwarnai semangat mengembangkan potensi diri dan memanfaatkannya untuk mencapai kebahagiaan lahir dan batin serta keselamatan dunia akherat (Zuchdi, 2008:141). Dengan kata lain, lembaga pendidikan dalam konteks penelitian ini diharapkan dapat menghasilkan terbentuknya manusia yang cerdas dan humanis, serta tidak mudah terpancing emosi. Dalam hal ini mereposisi pendidikan seni dapat dipandang sebagai proses pembentukan kualitas manusia yang bermuara pada aspek kecerdasan dan akhlak mulia yang berujung pada proses humanisasi.

Tampaknya aspek yang membentuk insan humanis tidak dapat dielakkan dari proses pembelajaran dalam pendidikan seni. Oleh karenanya, agar lebih terfokus, secara rinci penelitian ini diharapkan dapat menjawab permasalahan, di antaranya sebagai berikut. (1) Bagaimanakah bentuk pembelajaran seni dapat menjadi wahana proses pembentukan insan humanis? (2) Apa saja yang menjadi indikator proses pembentukan insan humanis dalam proses pembelajaran seni?

\section{METODE}

Dalam penelitian ini dipergunakan pendekatan kualitatif. Dengan pendekatan ini, berbagai aspek yang diteliti akan dapat menghasilkan data yang valid, reliabel, dan relevan dengan yang didibutuhkan. Selain itu, dengan pendekatan kualitatif akan dapat dilakukan observasi yang lebih mendalam dan teliti terhadap objek-objek penelitian sehingga data-data yang diperoleh lebih akurat dan mendasar. 
Sebagai objek dalam penelitian ini adalah rekonstruksi proses pembelajaran seni tari sebagai sentra dan proses pembentukan insan humanis. Maksudnya, penelitian ini ingin mendeskripsikan pemikiran (konstruksi) para informan yang terlibat dalam proses pembelajaran seni tari sebagai wahana pembentukan karakter insan humanis. Mereka adalah subjek penelitian yang diharapkan dapat memberikan informasi, antara lain dosen, para mahasiswa seni tari, dan alumni. Di samping itu, para guru seni, seniman, budayawan dan ahli dalam bidang humaniora juga dijadikan sebagai subjek penelitian, antara lain: (1) Djoko Dwiyanto, Kepala Dinas Kebudayaan DIY yang banyak mengunjungi kelompok-kelompok kesenian di pelosok-pelosok DIY dan memahami interaksi para pelaku kesenian mulai dari latihan sampai pada pentas seninya; (2) Bakdi Sumanto, seorang sastrawan sekaligus budayawan yang mengetahui banyak tentang persoalan nilai-nilai kemanusiaan yang dapat digali melalui proses berkesenian; dan (3) Suminto A. Sayuti, seorang pendidik, penyair, sekaligus budayawan yang banyak mengetahui tentang posisi pendidikan seni kaitannya dengan nilai-nilai kemanusiaan. Mereka inilah para informan yang mengetahui banyak tentang persoalan seni dan humanisme.

Instrumen utama dalam penelitian ini adalah peneliti sendiri. Peneliti langsung turun ke lapangan, melakukan observasi di kelas pembelajaran seni tari dan wawancara dengan para informan. Sebelumnya peneliti telah mempersiapkan diri dengan membawa perbekalan yang siap membantu penelitian selama berada di lapangan. Perbekalan penelitian itu di antaranya adalah tape recorder dan buku catatan. Tape recorder dipergunakan untuk merekam jalannya wawancara, dan buku catatan dipergunakan untuk mencatat aktivitas observasi langsung di lapangan. Data yang terkumpul melalui hasil observasi, wawancara, dan dokumentasi ini berupa data kualitatif. Teknik yang dipergunakan untuk menganalisis data penelitian adalah teknik analisis deskriptif interpretatif.

\section{HASIL}

\section{Bentuk Pembelajaran Seni}

Lembaga pendidikan memiliki tugas mempersiapkan terbentuknya individu-individu yang cerdas dan berakhlak mulia. Terbentuknya dua kriteria ini memungkinkan terwujudnya kehidupan sosial yang ideal, yang diwarnai semangat mengembangkan potensi diri dan memanfaatkannya untuk mencapai kebahagiaan lahir batin serta keselamatan dunia akherat (Zuchdi, 2008:141). Dengan kata lain, lembaga pendidikan dalam konteks tulisan ini diharapkan dapat menghasilkan terbentuknya manusia yang humanis. Dalam hal ini, meletakkan kembali posisi pendidikan seni dapat dipandang sebagai proses pembentukan humanisasi peserta didik yang bermuara pada aspek kecerdasan dan akhlak mulia.

Dalam Undang-Undang Sisdiknas 2003 pasal 3 juga diungkapkan bahwa pendidikan nasional berfungsi untuk mengembangkan kemampuan dan membentuk watak serta peradaban bangsa yang bermartabat. Tujuannya adalah 
untuk mengembangkan potensi peserta didik agar menjadi manusia yang beriman, bertakwa, berakhlak mulia, sehat, berilmu, cakap, kreatif, mandiri, dan menjadi warga negara yang demokratis. Dengan demikian, pendidikan seni yang ditawarkan di atas layak diangkat sebagai basis pendidikan karakter untuk membawa peserta didik pada tujuan jangka panjangnya yakni berujung pada watak manusia yang humanis.

Ki Hajar Dewantara membuat konsep pendidikan yang disebut Tringo (ngerti, ngrasa, nglakoni). Ngerti artinya mengetahui ilmu yang diberikan (kognitif). Ngrasa artinya dapat merasakan ilmu yang telah diterima sehingga dapat menentukan sikap (afektif). Nglakoni artinya ilmu yang telah diterima dapat dipraktikkan dengan baik dan benar (psikomotorik). Dengan demikian, ia tidak merekomendasikan pendidikan yang melulu intelektualisme (cognitive/ngerti) saja, melainkan juga menyeimbangkan dengan afektif (ngrasa) serta psikomotorik (nglakoni) yang mengarah pada pembangunan karakter bangsa (Dwiarsa, 2010:2-3).

Pendidikan tidak sekadar mentransfer ilmu pengetahuan (transfer of knowledge) kepada peserta didik, tetapi lebih dari itu juga mentransfer nilai (transfer of value). Dalam pandangan ini, pendidikan seni memiliki potensi besar dalam mengolah ilmu pengetahuan sekaligus nilai-nilai kehidupan manusia secara langsung. Transfer ilmu dan nilai kepada para peserta didik tentu langsung terjadi ketika pembelajaran di kelas sedang berlangsung.
Berikut ini adalah sebuah pendeskripsian bentuk pembelajaran seni tari dengan mengambil contoh proses pembelajaran dalam mata kuliah Tari Surakarta. Tentang materi pokok bahasannya mengambil salah satu aspek dalam teori estetika seni, yaitu aspek "kontras". Dimensi seni di dalam seni rupa dan seni pertunjukan selalu dipenuhi aspek kontras. Dalam suatu lukisan ada kontras, entah itu kontras warna, garis, bidang, dan sebagainya. Demikian juga dalam seni pertunjukan juga terdapat kontras. Adapun materi dalam mata kuliah Tari Surakarta yang dijadikan sebgai model bentuk pembelajaran seni tari adalah tari BambanganCakil. Tari Bambangan-Cakil yang dipertunjukan di atas pangung, terlihat banyak aspek kontras, antara lain: (1) gerak tari tokoh Cakil yang sangat dinamis kontras dengan gerak tari yang dipresentasikan tokoh Bambangan yang sangat halus; dan (2) karakter kedua tokoh juga kontras, yaitu Bambangan berkarakter baik dan Cakil berkarakter jahat.

Ketika pembelajaran mata kuliah TariSurakarta berlangsung, para mahasiswa seni tari mendapat materi tarian Bambangan-Cakil. Tarian ini diperagakan dua orang secara berpasangan. Yang satu sebagai Bambangan dan yang lain sebagai Cakil. Kemudian, mereka disuruh untuk memperagakan tari Bambangan-Cakil secara bergantian, baik berperan sebagai Bambangan maupun Cakil. Dengan memperagakan tokoh Bambangan dan Cakil, para mahasiswa diharapkan dapat menjiwai terhadap tokoh yang berpihak pada kebenaran dan tokoh yang berpihak pada 
keburukan, dengan tujuan agar para peserta didik ini dapat mengambil hikmahnya, serta merenungkan nilainilai kehidupan yang berasal dari cerita pewayangan untuk ditransfer dalam praktik kehidupan sehari-hari.

Selanjutnya dosen menanyakan bagaimana perasaan dan kesan menjadi tokoh protagonis seperti memerankan tokoh Bambangan, dan tokoh antagonis seperti memerankan tokoh Cakil. Para mahasiswa diajak berdiskusi mengenai karakter tokoh Bambangan dan Cakil sehingga secara total proses pembelajaran di dalam kelas akan membawa seorang peserta didik pada pencapaian tiga ranah, yaitu: (1) ranah kognitif yaitu memahami ilmu pengetahuan tentang tari Bambangan-Cakil yang menjadi pijakan dari sebuah ilmu yang lebih besar bernama "Perang Kembang"; (2) ranah afektif, yaitu memahami nilai-nilai kehidupan yang tercermin dalam tari Bambangan-Cakil untukdisikapi; dan (3) peserta didik mempraktikkan tarian Bambangan dan Cakil secara bergantian. Demikian selanjutnya tari tersebut dipraktikkan mereka di dalam kelas setiap hari Selasa selama sekitar dua bulan. Selain itu, para peserta didik juga dituntut untuk mengadakan latihan mandiri di luar kelas. Pada tahap akhir, mereka harus mengikuti ujian di kelas, dengan persyaratan memakai busana dan rias tokoh Bambangan dan Cakil. Selain itu, mereka juga mempraktikkan dalam bentuk pentas seni di berbagai kesempatan di luar kelas sebagai permintaan masyarakat.

Setelah ujian selesai, mereka ditanya tentang perasaannya menjadi seorang tokoh baik (Bambangan) dan tokoh jahat (Cakil). Tentu saja mereka akan menjawab mengenai nilai-nilai kemanusiaan dalam tarian BambanganCakil. Di sinilah pendidikan seni berbicara langsung mengenai transfer of knowledge dan transfer of value yang diharapkan berdampak langsung pada diri peserta didik. Karya seni selalu berbicara tentang persoalan nilai-nilai kemanusiaan. Untuk memahami letak nilai-nilai kemanusiaan itu tergantung pada proses penghayatan yang diperoleh para peserta didik dalam kegiatan belajar mengajar dengan materi karya seni. Nilai-nilai kemanusiaan tersebut antara lain meliputi hal-hal sebagai berikut.

\section{Nilai Estetika}

Semua karya seni memiliki keindahan. Indikasi indah terlihat pada: (1) keutuhan (unity) antara bentuk dan isi karya seni; dan (2) keseimbangan (balance) dan keserasian (harmony) penampilan atau ekspresi karya seni. Nilai keindahan tampak lebih relatif, jika yang kita perhatikan adalah penilaian atau penghargaan terhadap kesenian. Sentuhan estetis dengan mengembangkan aspek rasa ini merupakan aspek kesempurnaan keindahan dalam karya seni, yang dihubungkan dengan bentuk, stuktur, komposisi, seta elemenelemen pertunjukan yang lain sebagai variasinya. Elemen-elemen pertunjukan dalam tarian Bambangan-Cakil antara lain: gerak tari, iringan musik, rias, busana, panggung, lampu, dan properti. Semuanya terlihat sempurna, utuh, imbang, dan serasi. 
Nilai estetika yang lain adalah nilai kesopanan dan budi pekerti atau ahklak. Hal tersebut dapat dilihat pada latihan dan pentasnya. Baik pemeran Bambangan mapun Cakil tampak sopan karena mereka menaati kaidah tradisi yang disebut pakem. Di dalam pakem disebutkan adanya aturan-aturan, misalnya pemeran Bambangan melakukan gerak tari mulai dari sembahan, melangkah dengan tenang, sampai berperang (dengan Cakil) juga dengan tenang. Dari nilai estetika ini diharapkan kepada peserta didik dapat membawanya untuk berinteraksi dengan masyarakat luas sehingga hasil interaksinya dapat menghasilkan persaudaraan yang sopan, utuh, imbang, dan serasi.

\section{Nilai Sosial}

Nilai sosial dalam karya seni terletak pada posisi orang-orang yang berkesenian atau bekerja secara bersamasama harus saling membantu dengan orang lain. Dalam kehidupan sosial, perilaku saling membantu akan menumbuhkan pada posisi masyarakat yang selaras dan seimbang. Peserta didik tidak bisa hidup sendiri terpisah dari peserta didik lainnya.

Ketika peserta didik akan memperdalam tarian Bambangan-Cakil, jika yang satu berperan sebagai Bambangan, yang lain harus latihan bersama dengan teman pasangannya yang berperan sebagai Cakil. Ia tidak dapat sendirian, mau tidak mau harus mencari teman pasangan untuk berlatih bersama. Lebih-lebih jika akan menempuh ujian, para peserta didik harus latihan bersama pasangannya secara ketat.
Pendek kata, mereka harus dapat membangun persahabatan, kebersamaan, sosialisasi, dan bekerja secara sinergis. Inilah salah satu nilai kemanusiaan yang didapat lewat proses latihan dan pentas sebuah karya seni. Hal ini belum menyangkut persoalan-persoalan kecil atau lain-lain di luar proses latihan dan pentas. Sebagai contoh, bagaimana para peserta didik merencanakan latihan, kencan waktu dan tempat latihan, menyiapkan perbekalan dan konsumsi yang harus dibawa. Dengan kata lain, banyak aspek tolong-menolong atau sosial yang harus ditempuh untuk mengikuti pendidikan seni.

\section{Nilai Moral}

Moral merupakan tingkah laku perbuatan manusia dipandang dari nilai baik-buruk, benar dan salah berdasarkan adab kebiasaan individu itu berada. Pesan-pesan moral yang terdapat padatarian Bambangan-Cakil dapat diambil peserta didik setelah memahami isi ceritanya,baik yang positif maupun negatif. Segi positif harus ditonjolkan sebagai hal yang patut ditiru dan diteladani. Demikian segi negatif perlu juga diketahui serta disampaikan kepada masyarakat. Hal ini dimaksudkan agar kita tidak tersesat, artinya bisa membedakan mana yang baik mana yang buruk.

Di dalam pokok bahasan tadi disebutkan tentang estetika dalam suatu seni. Bentuk dan isi karya seni menurut teori estetika ditentukan berdasarkan aspek-aspek seperti repetisi, dominasi, balans, intensitas, kontras, dan sebagainya. Dilihat dari aspek-aspek itu, sebuah karya seni selalu kelihatan indah. 
Untuk menjelaskan nilai moral dalam sebuah karya seni dapat mengambil salah satu aspek dalam teori estetika, yaitu aspek kontras. Istilah kontras dalam kehidupan sehari-hari sering dipersamakan dengan konflik, perpecahan, perceraian, benturan, ketegangan, dan kesenjangan. Salah satu kata tersebut, misalnya perpecahan kita ambil untuk diterapkan dalam cabang-cabang seni, antara lain adanya perpecahan warna dalam suatu lukisan, perpecahan nada dalam suatu musik, perpecahan gerak dalam suatu tarian, perpecahan suara dalam suatu teater, dan sebagainya. Tentu saja perpecahan ini bukan suatu perpecahan nyata, tetapi hanyalah perpecahan semu. Hal itu disebabkan perpecahan nada, warna, gerak tari, dan suara hanyalah perpecahan pada tataran medium seni. Padahal sesungguhnya dengan adanya perpecahan itu, lukisan, tarian, musik, dan tater tetap kelihtan indah (bagus, rapi, baik). Demikian juga dalam pertunjukan tari Bambangan-Cakil yang mempresentasikan dua tokoh sedang bertarung, meskipun dipenuhi dengan gerak-gerak tari serta karakter kedua tokoh yang amat kontras, ia merupakan sebuah karya seni yang sangat indah.

Hal inilah yang berbeda dengan perpecahan, konflik, benturan dalam dunia nyata. Contoh-contoh yang banyak muncul setiap saat dan dapat disaksikan secara langsung lewat televisi merupakan perpecahan nyata. Perang suku di Papua yang setiap saat dapat meletus. Peristiwa di kawasan Mbah Priuk Jakarta 2010 yang memicu ketegangan antara satuan polisi pa- mong praja dengan penduduk setempat hingga menewaskan orang dari kedua belah pihak, dan berbagai peristiwa di tanah air seperti pembakaran toko, pasar, hutan, dan gedung pemerintah merupakan akibat perpecahan sosial yang sulit untuk didamaikan. Dalam hubungan ini belum termasuk perpecahan dalam skala kecil yang terjadi dalam suatu keluarga, tubuh organisasi, lembaga sosial serta lembaga pemerintah yang sering memicu timbulnya kekerasan.

Dengan demikian, untuk menjernihkan perpecahan sosial itu, peserta didik dijelaskan dengan mengacu pada teori estetika. Salah satu aspek estetika yang menjadi pangkal penjelasan adalah teori kontras. Penjelasannya adalah kontras, perpecahan, atau konflik di dalam suatu karya seni itu indah. Di dalam dunia nyata,"marilah kontras yang indah di dalam karya seni itu kita terapkan dalam kehidupan seharihari". Di dalam kehidupan keluarga, masyarakat, organisasi tentu terdapat suatu yang kontras, tetapi marilah kontras itu kita jadikan sebagai sesuatu yang indah. Jika penjelasan ini dapat diwujudkan dalam kehidupan seharihari, berarti seorang peserta didik telah berhasil menjadi seseorang yang memiliki karakter humanis. Dalam artian pula bahwa nilai moral sangat melekat dalam tarian Bambangan-Cakil.

\section{Indikasi Proses Pembentukan Insan Humanis}

Yang menentukan karakter humanis terletak pada proses pembelajaran seni, yakni berupa hominisasi (pembentukan manusia) dan humanisasi 
(pengamalan kemanusiaan), melalui tahap-tahap (1) merencanakan untuk menentukan persiapan latihan dan pentas; (2) latihan bersama yang diulang-ulang di luar kelas tanpa dipantau oleh guru; (3) mempraktikkan di dalam kelas secara bersama-sama dengan pantauan guru; dan (4) yang terakhir dalam tahap ujian yang harus dilakukan secara bersama-sama melalui penilaian dari pihak guru. Total waktu yang diperlukan untuk menggapai proses tersebut (mulai no. 1 sampai no. 4) berlangsung sekitar dua bulan atau setengah semester. Hal ini dapat dilihat pada Kurikulum Jurusan Pendidikan Seni Tari, bahwa satu repertoar seni tari dan seni karawitan sebagai materi mata kuliah jenis praktik dipelajari selama dua bulan. Seperti dalam mata kuliah seni karawitan, dalam satu semester dipelajari dua materi. Ini menunjukan bahwa waktu satu semester yang biasanya berlangsung sekitar empat bulan harus dibagi dua waktu, masing-masing dua bulan untuk menempuh materi pertama dan kedua.

Proses yang memakan waktu cukup panjang untuk menghasilkan satu repertoar seni dalam suatu proses belajar mengajar seni itu masih tersirat banyak aspek yang mengiringi perjalanan untuk berproses. Dengan kata lain, terdapat hal-hal yang amat kompleks proses pembelajaran seni melalui tahap-tahap seperti dibicarakan sebelumnya. Contoh, setiap akan latihan, mahasiswa membawa bekal makanan dan minuman. Bekal ini sering dibagi dengan teman-temannya yang kebetulan tidak membawa apa-apa. Di ruang (non-kelas) dan waktu yang jauh lebih longgar dibanding dengan kelas, para peserta didik itu memperdalam materi yang telah diberikan dosen dengan cara yang leluasa dan sebebas-bebasnya, meskipun dalam segi-segi tertentu juga terdapat batas-batas kewajaran yang harus ditaati.

Dalam interaksinya di luar kelas, mereka saling memberi dan menerima (take and give) baik menyangkut materi perkuliahan maupun hal-hal di luar materi perkuliahan. Sebagai contoh, urunan untuk membeli makanan dan minuman. Yang paling sering terjadi, rasa mengalah untuk memberi kepada temannya, misalnya membawa fasilitas (tape recorder) dengan ikhlas karena temannya miskin yang hanya numpang ikut latihan bersama. Bahkan, temannya yang sudah menguasai sering diminta untuk melatih temannya yang ketinggalan di kelas, sehingga mereka trampil karena dibentuk lewat latihan bersama. Dalam proses latihan dan menyiapkan ujian, mereka saling membutuhkan untuk bekerja sama. Pada tahap ini peserta didik secara alami selalu tersenyum ketika berinteraksi dengan temannya, meskipun di dalam kurikulum tidak terdapat perintah untuk tersenyum. Jadi, masalah tersenyum ini bukan dibentuk, tetapi terbentuk sendiri melalui proses belajar seni. Di era sekarang tampaknya, tersenyum merupakan barang yang mahal seiring orang mulai hedonis, egois, dan individualistis. Sebagai catatan, seorang artis Neno Warisman pernah prihatin ketika menjadi juri di televisi swasta dalam kontes Pildacil (Pilihan Dai Cilik) karena 
melihat banyak ibu-ibu yang tidak mau tersenyum.

Sambil tersenyum disertai ucapan terima kasih, para peserta didik yang telah mendapat pengalaman dan konsumsi atau sebaliknya dari temannya pada ajang latihan di luar kelas merupakan bentuk making habit. Proses pembelajaran seni ini lama-kelamaan menjadikan peserta didik selalu tersenyum sehingga mereka mejadi seseorang yang humanis.

Seorang mahasiswa pendidikan seni dari Jepang yang sedang belajar di ISI Surakarta, Kaori Okado menjelaskan bahwa anak-anak yang berlatih seni karawitan Jawa, yang tadinya berperangai keras menjadi lembut. Lewat pembelajaran seni tersebut, rasa solidaritas juga tumbuh semakin tinggi karena mereka bisa saling menghormati sesama teman. Bahkan proses pendidikan seni tersebut juga dapat membentuk manusia yang berhati sabar dan tekun. Ia menandaskan bahwa dari proses pembelajaran seni karawitan sebenarnya kita banyak mendapatkan pelajaran hidup, yaitu belajar bersabar dan bersosialisasi dengan orang lain sehingga kita bisa menghargai orang lain.

Proses pendidikan seni tersebut juga dapat membentuk manusia yang berhati lembut juga dirasakan oleh seorang mahasiswa bernama Suwondo. Ia mangaku sewaktu sekolah di SMA bergabung dengan para gali. Karakter para gali yang keras mempengaruhi dirinya memiliki watak keras. Selama dalam proses menjadi mahasiswa di lembaga kesenian, terjadi perubahanperubahan yang sangat mendasar pada dirinya. Wataknya yang tadinya keras berubah total menjadi halus, dan mulai sering bertegur sapa kepada banyak orang serta mementingkan kerjasama yang sinergis dengan orang lain. Ia menyadari bahwa belajar seni tanpa orang lain tidak akan berhasil. Dari penjelasan tentang proses pembelajaran secara empiris tersebut, dapat dipetik hikmah bahwa pendidikan seni dapat membentuk insan humanis.

Proses yang membentuk karakter humanis seseorang ini penting untuk kita reposisikan, bahwa sesungguhnya pendidikan seni merupakan basis pembentukan karakter humanis. Dalam arti, jika dalam ranah pendidikan seni hanya mengarah pada penguasaan repertoar atau secara teknis mencapai kemahiran, tetapi tanpa membahas nilai-nilai etika kehidupan, sangatlah rugi sebagai tujuan pembelajaran.

Sekiranya proses humanisasi melalui pendidikan seni yang diaktualisasikan dalam satu paket pembelajaran tari Bambangan-Cakil masih ditambah banyak materi tarian lain, di antaranya tarian yang tergolong berasal dari daerahnya senidiri, daerah lain, serta tari mancanegara. Dalam hal ini peserta didikmengenal, mempelajari dan mempraktikkan tidak hanya budaya milik sendiri tetapi juga budaya daerah lain dan manca negara.

Selain itu, peserta didik dalam berkecimpung di dalam pendidikan seni ini, sesuai kurikulum Jurusan Pendidikan Seni Tari, mereka harus mempelajari seni karawitan selama tiga semester. Proses pembelajaran seni karawitan sangat memperkuat aspek perasaan (afektif) dan nilai sosial karena 
cara belajarnya mutlak harus dilakukan bersama. Hal ini disebabkan proses kegiatan belajar mengajar materi seni karawitan membutuhkan kesadaran serta kesabaran, sebagaimana diutarakan Kaori Okado. Para peserta didik mau tidak mau harus melakukan sosialisasi atau bekerja sama dengan temannya. Menurut Warwanto (2009: 57), kerjasama yang dibangun peserta didik dipergunakan untuk menumbuhkan, menghayati, dan mengamalkan nilai-nilai kemanusiaan.

Di sinilah terlihat bahwa pendidikan seni secara langsung merupakan perwujudan proses pendidikan karakter. Cara belajarnya tidak hanya bersifat teoretis, akan tetapi secara langsung mempraktikkan baik secara akademis maupun di luar akademis. Secara akademis, peserta didik belajar di kelas, dan di luar akademis mereka harus melakukan latihan dan kadangkadang mempraktikkan dalam bentuk pentas yang diminta masyarakat, misalnya dalam hajatan keluarga, upacara desa, festival budaya, dan kepentingan pihak atau institusi tertentu yang setiap saat memerlukan pentas seni.

Jika dilihat secara humanistis, yang lebih penting dalam proses pendidikan seni adalah terlibatnya aspek sosial secara langsung baik di dalam lingkup akademis maupun di luar akademis. Di dalam lingkup akademis, proses sosialisasi seperti harus saling kerjasama itu bersifat formal. Tetapi, di luar akademis justru aspek sosial muatannya jauh lebih banyak dibanding dengan di dalam lingkup akademis. Sebagai contoh, melaksanakan latihan di luar lingkup akademik yang berlangsung ma- lam hari. Latihan ini merupakan bentuk pembelajaran mandiri dan efektif yang wajib dilakukan peserta didik. Semakin banyak latihan yang ditempuh, semakin mendalam dalam mempelajari materi seni.

Hal ini sama dengan membaca buku. Semakin banyak waktu yang digunakan untuk membaca buku, akan semakin banyak hal yang diketahui. Demikian pula sebelum para mahasiswa datang latihan seni pada malam hari, mereka harus mempersiapkan diri dari rumah dengan membawa perbealan seperti makanan, properti seni, tape recorder, mengajak teman lain yang kadang-kadang tidak seprofesi. Semuanya memerlukan bantuan pihak lain dalam bentuk kerjasama, gotongroyong, dan kekeluargaan. Di samping itu yang sangat penting untuk tidak dilupakan adalah hati yang ikhlas, siap membantu teman-teman yang membutuhkan. Sebagai contoh, seorang mahasiswa berasal dari Kalimantan Timur yang merasa kesulitan untuk mempelajari tari Jawa, meskipun telah mengikuti kegiatan kuliah tari Jawa yang diampu oleh seorang dosen. Kemudian ia meminta bantuan temannya yang berasal dari Jawa untuk belajar tari Jawa. Dengan semangat yang tinggi, akhirnya ia berhasil mempelajari tari Jawa. Ia merasa mampu belajar tari Jawa, karena banyak ditolong orang Jawa. Dari sinilah, ia menjelaskan bahwa belajar tari Jawa tidak dapat individualistis, tetapi selalu membutuhkan kerjasama yang sinergis dengan orang lain. Dengan kata lain, pendidikan seni mengandung banyak muatan humanistis. Dalam kurun waktu sekitar empat 
sampai lima tahun, peserta didik dalam proses pembelajaran misalnya pada Jurusan Pendidikan Seni Tari secara langsung telah membangun kebiasaan (making habit) pendidikan karakter menuju pada insan humanis. Driyarkara (2006:70-76) menyatakan, bahwa semua indikasi ini merupakan hominisasi (pembentukan manusia) dan humanisasi (pengamalan kemanusiaan).

\section{PENUTUP}

Sekiranya proses humanisasi melalui pendidikan seni diaktualisasikan dalam suatu paket pembelajaran dengan materi seni. Bentuk pembelajarannya menyertakan aspek-aspek: cognitif, afektif, dan psikomotorik dan masih ditambah aspek sosial. Dalam hal ini peserta didik mengenal, mempelajari, merasakan dan mempraktikan materi seni sesuai kurikulum. Proses pembelajaran seni pada umumnya memperkuat aspek perasaan (afektif) dan nilai sosial karena cara belajarnya mutlak harus dilakukan bersama. Di sinilah terlihat bahwa pendidikan seni penting untuk direposisi, karena ia merupakan perwujudan proses pendidikan karakter menuju pada tata laku manusia yang humanis.

Adapun identifikasi terbentuknya peserta didik yang mencerminkan sebagai insan humanis adalah semangat untuk melakukan kerja sama, gotongroyong, dan kekeluargaan baik di lingkungan tempat belajar maupun masyarakat. Di samping itu juga terdapat aspek yang sangat penting dalam melakukan pembelajaran seni yakni hati yang ikhlas, siap membangun prestasi dirinya sendiri dan membantu teman- temannya yang membutuhkan terutama dalam meniti karier pendidikan seni. Dengan kata lain, pendidikan seni mengandung banyak muatan humanistis. Proses pembelajarannya secara langsung telah membangun kebiasaan (making habit) pendidikan karakter menuju pada insan humanis.

Temuan penelitian ini perlu direspon oleh pihak terkait, mengingat pendidikan seni selama ini menjadi pendidikan marginal dalam arti pendidikan ini kurang disenangi masyarakat, termasuk mata pelajaran seni di sekolah. Sekiranya temuan penelitian ini dapat diterapkan untuk proses pembelajaran di sekolah, karena fenomena sosial kenakalan remaja di sekolah semakin tahun menunjukkan gejalan yang memprihatinkan, dan pendidikan seni tampaknya dapat menjadi solusi fenomena tersebut.

\section{UCAPAN TERIMA KASIH}

Pada kesempatan ini perkenankan peneliti menyampaikan ucapan terima kasih kepada Prof. Darmiyati Zuchdi, Ed.D.yang telah menulis buku berjudul Humanisasi Pendidikan: Menemukan Kembali Pendidikan yang Manusiawi dan Prof. Dr. N. Driyarkara, SJ. (almarhum) melalui bukunya berjudul Hominisasi dan Humanisasi: Telaah Filsafat Pendidikan. Penelitian ini banyak mendapat inspirasi dari dua buku tersebut, terutama mengenai konsep humanisasi di dalam pendidikan. Selain itu, ucapan terima kasih ditujukan kepada Romo Dr. Bernhard Kieser, Ketua Perpustakaan Colose St. Ignatius Yogyakarta yang telah menerima peneliti untuk membaca buku-buku, jurnal-jurnal, dan 
makalah-makalah yang membahas tentang humanisasi dan pendidikan.

\section{DAFTAR PUSTAKA}

Adeline. 2005. "Eksistensialisme dan Humanisme Sartre". Jurnal Filsafat Driyarkara Tahun XXVIII, No. 1., pp. 81-95.

Dewantara, Ki Hadjar. 2004. Pendidikan. Kumpulan Karangan. Yogyakarta: Taman Siswa.

Driyarkara, N. 2006. Hominisasi dan Humanisasi: Telaah Filsafat Pendidikan. Yogyakarta: Universitas Sanata Dharma.

Dwiarsa, Priya. 2010. “Implementasi Pendidikan Karakter Melalui Kearifan Lokal di Perguruan Tamansiswa". Makalah Dipresentasikan dalam Seminar Nasional Implementasi Pendidikan Karakter dalam Praksis Pendidikan dan Pembelajaran. FBS UNY, Yogyakarta, 20 November.

Warwanto, Heribertus Joko. 2009. Pendidikan Religius: Gagasan, Isi, dan Pelaksanaannya. Yogyakarta: Kanisius.
Naim, Ngainun dan Achmad Sauqi. 2008. Pendidikan Multikultural: Konsep dan Aplikasi. Yogyakarta: Ar-Ruzz Media.

Sastrapratedja, M. 2001. Pendidikan sebagai Humanisasi. Yogyakarta: Penerbit Universitas Sanata Dharma.

Santosa, Thomas. 2002. Konstruksi Sosial tentang Kekerasan terhadap Pembakaran Gereja di Situbondo 1996. Disertasi-S3. Program Pascasarjana, Universitas Airlangga. Surabaya.

Zuchdi, Darmiyati. 2008. Humanisasi Pendidikan: Menemukan Kembali Pendidikan yang Manusiawi. Jakarta: Bumi Aksara.

Wils, Jean Pierre. 2002. "Kekerasan Sebagai Ketentuan Antropologis? Menuju Evaluasi Baru", dalam Wim Beuken dan KarlJosef Kuschel (et. al.). Agama sebagai Sumber Kekerasan. Terjemahan. Yogyakarta: Pustaka Pelajar. 